\title{
Determination of Heavy Metals and Anti-nutrient Residues in Selected Organs of Bovines Commonly Slaughtered in Federal Polytechnic Mubi, Adamawa State, Nigeria
}

\author{
Ismaila Yada Sudi*1, Ibrahim Sanusi*1, \\ Maryam Usman Ahmed ${ }^{1}$, Clifford L. Barnabas ${ }^{2}$ \\ ${ }^{1 *}$ Department of Biochemistry, \\ Faculty of Sciences, \\ Adamawa State University \\ Mubi, Nigeria. \\ ${ }^{2}$ Department of Biochemistry, \\ Faculty of Life Sciences, \\ Ahmadu Bello University \\ Zaria, Nigeria. \\ Email: yada280@gmail.com
}

\begin{abstract}
This study was conducted to determine the concentrations of heavy metals (Lead, Chromium, Copper, Cadmium and Zinc) and anti-nutrients residues (phytate and oxalate) in cattle (bovines) organs slaughtered at Federal Polytechnic Mubi, Nigeria slaughterhouse. Different organs (kidney, liver, lungs, heart and spleen) were collected randomly from five different bovines as samples from slaughterhouse and were brought to the laboratory for analysis. All of the heavy metals analyzed were detected with Lead presenting $293.07 \pm 163.53 \mathrm{mg} / \mathrm{kg}$ in lung, $2.97 \pm 0.39 \mathrm{mg} / \mathrm{kg}$ Zinc in heart, $0.632 \pm 0.3724 \mathrm{mg} / \mathrm{kg}$ Cadmium, $1.53 \pm 1.482 .9722 .97 \pm 0.39 \mathrm{mg} / \mathrm{kg}$ Copper, $4.0 E^{-4} \pm 2.0 E^{-4}$ $\mathrm{mg} / \mathrm{kg}$ Chromium in liver, while highest concentration $0.63 \pm 0.37 \mathrm{mg} / \mathrm{kg}$ of Cadmium and $1.53 \pm$ $1.48 \mathrm{mg} / \mathrm{kg}$ Copper was found in spleen. The concentrations of Lead, Zinc, Copper, Cadmium and Chromium detected exceeds the recommended maximum acceptable levels proposed by the World Health Organization (WHO) which are Cadmium $0.5 \mathrm{mg} / \mathrm{kg}$, Lead $0.30 \mathrm{mg} / \mathrm{kg}$, Zinc $0.2 \mathrm{mg} / \mathrm{kg}$, Chromium $1.00 \mathrm{mg} / \mathrm{kg}$, Copper 0.1- $0.50 \mathrm{mg} / \mathrm{kg}$. The results from this study indicate that heavy metal toxicity could result from the consumption of organs of bovines (cows) feed within contaminated areas of Federal Polytechnic Mubi, Adamawa State, Nigeria.
\end{abstract}

Keywords: Anti-nutrient, Bovines, Heavy metals, Organs, Slaughter

\section{INTRODUCTION}

The safety of food is a major concern to the public worldwide. Food safety refers to handling, preparing and storing food in a way to best reduce the risk of individuals becoming sick from foodborne illnesses (Izah et al., 2017). Food poisoning has been associated with consumption of food materials contaminated with pesticides, heavy metals and/or toxins (Mello, 2003). Food poisoning is an illness due to eating or drinking water 
contaminated with bacteria, parasites or chemicals. The main sources of proteins, carbohydrates, vitamins, and minerals which are utilized by the human body for effective functioning of the organs/systems and growth are food resources. These food resources are mainly obtained from vegetation/plants (cereals, legumes and fruits etc.) and animals (some species of mammals, cattle, goat, fishes etc.) (Izah et al., 2017). Meat is mainly derived from the flesh of animals, which could be easily contaminated. After slaughtering, the meats are processed into different forms such as smoking, frying and boiling. These are the three main forms through which meat is consumed. In a developing country like Nigeria, meat products are usually acquired from the wild "bush-meat" and also domesticated animals (Kigigha et al., 2015).

This research was carried out within a polluted environment that has been a major problem of heavy metals contamination in Mubi. There was the need to determine this heavy metals toxicity in different areas where animals such as bovines are grazing, and to determine these heavy metals and anti-nutrients in different organs of bovines meat around Federal Polytechnic, Mubi consumed daily by humans. Certainly, problems were encountered in nature of grazing; therefore, heavy metals and anti-nutrients in food pose a serious threat to well-being of humans due to their toxicity and chelating activities. It is therefore necessary to determine the levels of heavy metals and anti-nutrients residues in different organs of bovines meat, because most of the bovines are feed or grazed in a contaminated or polluted area.

\section{MATERIALS AND METHODS}

\section{Study area}

Federal Polytechnic Mubi, is in Mubi town, located in the Northern Senatorial Zone of Adamawa State, Nigeria, between latitudes $9^{\circ} .30^{\prime}, 11^{\circ} 00^{\prime} \mathrm{N}$ and longitudes $12^{\circ} 00,13^{\circ} 45^{\prime} \mathrm{E}$ and has elevation of $581 \mathrm{~m}$ above sea level, situated at the foot of the Mandara mountains which separates Nigeria from the Republic of Cameroon. The slaughterhouses are located between the fisheries department of Adamawa State University and the animals' house. The climate of the area corresponds to other areas of the Mubi town which have been comprehensively documented. Furthermore, the area is characterized by atmospheric temperature of 15 to $48^{\circ} \mathrm{C}$ and a tropical climate of wet and dry (Aw) season all year round. (Maclean, 2017).

\section{Sample collection}

Random selection technique was used in this study. A total of twenty-five (25) different organs (kidney, Liver, lungs, heart, and spleen) from five (5) bovines as samples at Federal Polytechnic, Mubi slaughterhouse were collected from the point of slaughtering. All samples were properly labeled and stored in clean polyethylene bags according to their types of collection and were brought to the laboratory for preparations and treatments.

\section{Preparation and treatment of samples}

The samples collected were rinsed with distilled water to remove any contaminant. The samples were cut to small pieces using clean knife, and were dried in an air oven (Gallenkamp) at $100^{\circ} \mathrm{C}$ for 2 hours. After drying, the samples were ground into a fine powder using a pestle and mortar and stored in sample bottles for analysis. 


\section{Digestion}

Acid mixture $\left(10 \mathrm{~mL}, 70 \%\right.$ high purity $\mathrm{HNO}_{3}$ and $\left.65 \% \mathrm{HClO}_{4}, 4: 1 \mathrm{v} / \mathrm{v}\right)$ were added to the beakers containing $0.5 \mathrm{~g}$ each dry samples according to AOAC (1995). The mixture was digested using Kjal Digestion Block (Gerhardt Kjeldatherm) at $285^{\circ} \mathrm{C}$ till the transparent solution was achieved. After cooling, the digested samples were filtered using Whatman no. 42 filter paper and the filtrate was diluted to $50 \mathrm{~mL}$ with deionized water. The concentrations of Lead $(\mathrm{Pb})$, Chromium $(\mathrm{Cr})$, Copper $(\mathrm{Cu})$, Cadmium $(\mathrm{Cd})$, and Zinc $(\mathrm{Zn})$ were determined by an Atomic Absorbance Spectrophotometer (AAS) (Adebayo et al., 2009).

\section{Preparation of standard solution}

Determination of heavy metal standard stock solution $(1000 \mathrm{mg} / \mathrm{L})$ of each of the following; Lead, Copper, Cadmium, Zinc, and Chromium were prepared and diluted to the corresponding working standard solutions for heavy metal. All reagents used were of in analytical grade (AOAC, 1995).

\section{Determination of heavy metals}

Lead nitrate $(1.00 \mathrm{~g})$ was dissolved in $50 \mathrm{~mL}$ of $2 \mathrm{M}$ nitric acid. The solution was then made up to mark in $1 \mathrm{~L}$ volumetric flask with deionized water. Cadmium nitrate $(1.0 \mathrm{~g})$ was dissolved in $20 \mathrm{~mL}$ of $5 \mathrm{M}$ hydrochloric acid and 2 drops of concentrated Nitric acid was added. The resulting solution was made up to mark in $1 \mathrm{~L}$ volumetric flask with deionized water. Chromium nitrate $\left.\left(\mathrm{Cr}\left(\mathrm{NO}_{3}\right)_{3}\right) \cdot 9 \mathrm{H}_{2} \mathrm{O}\right)(7.696 \mathrm{~g})$ was dissolved in $250 \mathrm{~mL}$ of deionized water. The solution was then made up to mark in $1 \mathrm{~L}$ volumetric flask with deionized water. Zinc sulphate $(1.0 \mathrm{~g})$ was dissolved in $30 \mathrm{~mL}$ of $5 \mathrm{M} \mathrm{HCl}$. The resulting solution was then made up to mark in a $1 \mathrm{~L}$ volumetric flask with deionized water. Copper sulphate $(1.0 \mathrm{~g})$ was dissolved in $50 \mathrm{~mL}$ of $5 \mathrm{M}$ nitric acid. The solution was then made up to mark in a $1 \mathrm{~L}$ volumetric flask with deionized water.

\section{Determination of anti-nutrients}

The titration method as described by Day and Underwood (1986) was followed. $1 \mathrm{~g}$ of sample was weighed into $100 \mathrm{~mL}$ conical flask. Seventy-five $(75 \mathrm{~mL})$ of $3 \mathrm{M} \mathrm{H}_{2} \mathrm{SO}_{4}$ was added and stirred for $1 \mathrm{~h}$ with a magnetic stirrer. This was filtered using a What-man No 1 filter paper. Twenty five (25) $\mathrm{mL}$ of the filtrate was taken and titrated against $0.05 \mathrm{M} \mathrm{KMnO}_{4}$ solution until a faint pink color persisted for at least $30 \mathrm{~s}$. The content of oxalate was then calculated by taking $1 \mathrm{~mL}$ of $0.05 \mathrm{M} \mathrm{KMnO}_{4}$ as equivalent to $2.2 \mathrm{mg}$ oxalate.

The test samples $(0.2 \mathrm{~g})$ was dissolved in $100 \mathrm{~mL}$ of $2 \% \mathrm{HCl}$ and allowed to stand (digest) for 3 hours, then filtered. $50 \mathrm{~mL}$ of the filtrate was measured and put in a $250 \mathrm{~mL}$ conical flask, then $10 \mathrm{~mL}$ of $0.3 \% \mathrm{NH}_{4} \mathrm{SCN}$ was added as an indicator and $100 \mathrm{~mL}$ of distilled water was added to reach the proper acidity. Then, the solutions were titrated with $\mathrm{FeCl}_{3}$ which contain $0.00195 \mathrm{~g}$ of $\mathrm{Fe}$ per $\mathrm{cm}^{3}$ of iron (iii) chloride solution (Aina et al., 2012).

The percentage composition of phytate (phytic acid) was calculated as;

Percentage of phytate $=1 / 2 \times$ Titre value $\times 0.00195 \times 1.19 \times 100$

\section{Statistical Analysis}

The results were expressed as Mean $\pm \mathrm{SD}$, the differences between means analyzed were assayed using two-way analysis of variance (ANOVA) down the column. Significance differences was taken at $\mathrm{p}<0.05$ using Analystat Version 1.6.50.

\section{RESULTS}

The results of concentration of heavy metal were given in table 1 , the results showed that Cadmium, was detected in all the organs sampled and varied in the range of $0.01 \mathrm{mg} / \mathrm{kg}$ to 
$0.63 \mathrm{mg} / \mathrm{kg}$. The highest concentration $(0.63 \pm 0.37 \mathrm{a} \mathrm{mg} / \mathrm{kg})$ of Cadmium was found in the spleen while the lowest $\left(0.01 \pm 0.04^{\mathrm{c}} \mathrm{mg} / \mathrm{kg}\right)$ in the kidney, which is above the permissible limit of $0.50 \mathrm{mg} / \mathrm{kg}$, as recorded by USDA, (2006).

Zinc was detected in different organs samples and varied in the range of $1.74 \pm 1.41 \mathrm{mg} / \mathrm{kg}$ to $2.97 \pm 0.39 \mathrm{mg} / \mathrm{kg}$. The highest concentration was found in the Heart $(2.97 \pm 0.39 \mathrm{mg} / \mathrm{kg})$ while the lowest in the kidney $(1.74 \pm 1.41 \mathrm{mg} / \mathrm{kg})$ which were above the permissible limit of $0.2 \mathrm{mg} / \mathrm{kg}$, as recorded by USDA, (2006).

Chromium was detected in three different organs and varied from the range of $4.0 \mathrm{E}^{-4} \pm 2.0 \mathrm{E}^{-4}$ $\mathrm{mg} / \mathrm{kg}$ to $1.0 \mathrm{E}^{-4} \pm 1.0 \mathrm{E}^{-4} \mathrm{mg} / \mathrm{kg}$. The highest concentration of Chromium was found in the liver $\left(4.0 \mathrm{E}^{-4} \pm 2.0 \mathrm{E}^{-4} \mathrm{mg} / \mathrm{kg}\right)$ while the lowest $\left(1.0 \mathrm{E}^{-4} \mathrm{mg} / \mathrm{kg}\right)$ in the lung. The Chromium level in the organs sampled was found to be higher than the tolerable level of $1.0 \mathrm{mg} / \mathrm{kg}$.

The highest concentration of Lead $(293.07 \pm 163.53 \mathrm{mg} / \mathrm{kg})$ was found in lung and the lowest $\left(1.0 \mathrm{E}^{-4} \pm 1.0 \mathrm{E}^{-4} \mathrm{mg} / \mathrm{kg}\right)$ in kidney, which is far above the tolerable limit of $0.30 \mathrm{mg} / \mathrm{kg}$ set by WHO, (1984).

Copper, was detected in all the organs sampled and varied in the range of $0.10 \mathrm{mg} / \mathrm{kg}$ to $1.53 \mathrm{mg} / \mathrm{kg}$. The highest concentration $\left(1.53 \pm 1.48^{\mathrm{a}}\right)$ of Copper was found in the spleen while the lowest $(0.10 \pm 0.047 \mathrm{~b})$ in the liver, which is above the permissible limit of $0.50 \mathrm{mg} / \mathrm{kg}$, as recorded by USDA, (2006).

Table. 1: Concentration of heavy metals detected in selected Organs of bovines.

\begin{tabular}{ccccccc}
\hline S/N & Organ & $\begin{array}{c}\mathbf{C d} \\
(\mathbf{m g} / \mathbf{k g})\end{array}$ & $\begin{array}{c}\mathbf{Z n} \\
(\mathbf{m g} / \mathbf{k g})\end{array}$ & $\begin{array}{c}\mathbf{C r} \\
(\mathbf{m g} / \mathbf{k g})\end{array}$ & $\begin{array}{c}\mathbf{P b} \\
(\mathbf{m g} / \mathbf{k g})\end{array}$ & $\begin{array}{c}\mathbf{C u} \\
(\mathbf{m g} / \mathbf{k g})\end{array}$ \\
\hline 1 & Kidney & $0.01 \pm 0.04^{\mathrm{c}}$ & $1.74 \pm 1.41^{\mathrm{a}}$ & $2.0 \mathrm{E}^{-4} \pm 2.0 \mathrm{E}^{-4 \mathrm{~b}}$ & $1.0 \mathrm{E}^{-4} \pm 1.0 \mathrm{E}^{-4 \mathrm{a}}$ & $0.26 \pm 0.141^{\mathrm{b}}$ \\
2 & Liver & $0.04 \pm 0.01^{\mathrm{b}}$ & $2.76 \pm 0.44^{\mathrm{b}}$ & $4.0 \mathrm{E}^{-4} \pm 2.0 \mathrm{E}^{-4 \mathrm{c}}$ & $1.43 \pm 0.64^{\mathrm{a}}$ & $0.10 \pm 0.047^{\mathrm{b}}$ \\
3 & Lungs & $0.42 \pm 0.46^{\mathrm{a}}$ & $1.84 \pm 0.35^{\mathrm{a}}$ & $1.0 \mathrm{E}^{-4} \pm 1.0 \mathrm{E}^{-4 \mathrm{a}}$ & $293.07 \pm 163.53^{\mathrm{b}}$ & $1.31 \pm 1.09 \mathrm{a}$ \\
4 & Heart & $0.14 \pm 0.25^{\mathrm{b}}$ & $2.97 \pm 0.39^{\mathrm{b}}$ & $\mathrm{ND}$ & $5.32 \pm 7.77^{\mathrm{c}}$ & $0.65 \pm 0.21^{\mathrm{c}}$ \\
5 & Spleen & $0.63 \pm 0.37^{\mathrm{a}}$ & $2.96 \pm 0.27^{\mathrm{b}}$ & $\mathrm{ND}$ & $\mathrm{ND}$ & $1.53 \pm 1.48^{\mathrm{a}}$ \\
$\begin{array}{l}\text { WHO/FOA } \\
(1984)\end{array}$ & Organs & 0.5 & 0.2 & 1.00 & 0.30 & $0.1-0.50$ \\
\hline
\end{tabular}

Note; ND $=$ Not detected. The values in the table are presented in mean \pm standard deviation $[\mathrm{M} \pm S D] . \mathrm{p}<0.05$. Differences between means analyzed were assayed using two-way analysis of variance (ANOVA) down the column.

The concentration of anti-nutrients, phytate and oxalate are presented in table 2 below. The results showed that phytate was detected in different samples and varied from the range of $1.17 \pm 0.50 \mathrm{mg} / \mathrm{kg}$ to $0.08 \pm 0.13 \mathrm{mg} / \mathrm{kg}$. The results indicated that, there were no much significant differences in phytate concentrations in the different organs and they were far below the permissible limit set by FAO standard. The oxalate concentrations also showed no much significant differences between the different organs and there were below the permissible limit set by food standards. The maximum permissive level of oxalate in human is $40-50 \mathrm{mg}$ / day and in ruminants it is < $2 \%$ (WHO 1984). 
Table 2: The Anti-Nutrients Concentration of Phytate and Oxalate in Different Organs of Bovines.

\begin{tabular}{cccc}
\hline S/NO & ORGAN & $\begin{array}{c}\text { PHYTATE } \\
(\mathbf{m g} / \mathbf{g})\end{array}$ & $\begin{array}{c}\text { OXALATE } \\
(\mathbf{m g} / \mathbf{g})\end{array}$ \\
\hline $\mathbf{1}$ & Kidney & $0.90 \pm 0.15^{\mathrm{a}}$ & $1.74 \pm 0.45^{\mathrm{a}}$ \\
$\mathbf{2}$ & Liver & $0.79 \pm 0.07^{\mathrm{a}}$ & $1.91 \pm 0.36^{\mathrm{b}}$ \\
$\mathbf{3}$ & Lungs & $0.84 \pm 0.06^{\mathrm{a}}$ & $1.92 \pm 0.36^{\mathrm{b}}$ \\
$\mathbf{4}$ & Heart & $1.17 \pm 0.50^{\mathrm{b}}$ & $1.59 \pm 0.38^{\mathrm{c}}$ \\
$\mathbf{5}$ & Spleen & $0.08 \pm 0.13^{\mathrm{a}}$ & $1.75 \pm 0.44^{\mathrm{a}}$ \\
\hline
\end{tabular}

The values in the table above were presented in mean \pm standard deviation $[\mathrm{M} \pm \mathrm{SD}] . \mathrm{p}<0.05$. Differences between means analyzed were assayed using two-way analysis of variance (ANOVA) down the column.

\section{DISCUSSION}

Heavy metals were detected in the selected organs and they are highly toxic even at trace concentration. In biodiversity, heavy metals are being broadly utilized as a group name for metals and metalloids that have been associated with contamination and potential toxicity or eco-toxicity. Heavy metals in general are not - biodegradable, have long biological halflife and the potential for accumulation in the different organs of bovines Leading to unwanted side effects. From this study, the levels of heavy metals determined in different organs were above the permissible limit set by FAO standards, only Cadmium in kidney was found to be within the normal range.

Different studies have shown Cadmium concentrations were higher in the lungs and spleen than in the livers and kidneys (Hetcht et al., 1984). The higher concentration of Cadmium in the organs is due to the detoxification where these metals are accumulated (Aranha, 1994; Stokey et al., 1995). Exposure of animals to heavy metals could Lead to accumulation in their lungs, livers and spleen as their free protein-thiol content Leading to a strong fixation of heavy metals. Despite the excretory mechanism for such metals, which is based on low molecular compounds with -SH groups, vertebrates could not develop these mechanisms during the period of evaluation.

Zinc concentration were detected in all the organs, the highest concentration was detected in the heart and the lowest concentration was detected in kidney, the concentration in lungs, spleen and liver have a related similar concentration. Zinc substantially accumulates in the heart, liver and then spleen. It acts to diminish the toxicity, Zinc may be a modifier of the carcinogenic response; excessive levels of Zinc may enhance susceptibility to carcinogens, in few instances of acute Zinc poisoning are manifestations include nausea, vomiting, diarrhea, fever, and lethargy. Zinc is an essential trace metal it occurs in most foodstuffs and beverages, the main Zinc intake is in meats, especially organ meats, whole grain cereals and milk product including cheese. Zinc is essential component of many metal enzymes (Vallee and Auld, 1990).

Chromium concentration was detected in kidney, liver and lungs which are above the permissible limits set by the standards, only heart and spleen are not detected. Liver have the highest concentration than other two organs (kidney and lungs). Chromium is an essential element which assists the body to use sugar, protein and fat, and is internationally recognized as one of the most carcinogenic metals (Xia et al., 2019). In humans the oral route 
exposure to $\mathrm{Cr}$ is due to contamination of foodstuffs. Certain effects have been reported like mouth ulcers, indigestion, acute tubular necrosis, vomiting, abdominal pain, kidney failure and even death. It has been studied that $\mathrm{Cr}$ (III) has an essential role in protein and lipid metabolism but there are studies which has reported that $\mathrm{Cr}(\mathrm{III})$ cause oral toxicity in humans.

Lead was detected in the kidney, liver, lungs and heart but not detected in the spleen. The concentration of Lead was highest in all the study and was detected in lungs. Lead is a toxic metal, which has effect on organisms. Lead is regarded as a potent occupational toxin and its toxicological manifestations are well known. The non-biodegradable nature of Lead is the major reason for its prolonged persistence in the environment. Human exposure to Lead occurs via various sources such as bearings, soil, foods stuffs etc. Lead toxicity is a particularly insidious hazard with the potential of causing irreversible health effects. It is known to interfere with a number of body functions and it is primarily affecting the central nervous, hematopoietic, hepatic and renal system producing serious disorders. Lead toxicity is characterized by persistent vomiting, encephalopathy, lethargy, delirium, convulsions and coma, which occurs mainly through the respiratory and gastrointestinal (GI) tracts. About 30-40 percent of inhaled Lead is absorbed into the bloodstream, the amount absorbed in the gastrointestinal tract (GI) varies depending on nutritional status and age. Increased dietary intakes of magnesium, phosphate, and dietary fat have also been shown to decrease Lead absorption in gastrointestinal tract.

Copper is naturally present in most foodstuffs in the form of the Copper ions or Copper salts. The main sources are meat organs, offal, fish, pecans, milk, chocolate, and green vegetables. Copper is an essential metal which is involved in activities as diverse as hemoglobin synthesis, bone and elastic tissue development, and the normal function of the central nervous system. Acute toxicity is due to ingestion of high quantities of Copper salts is characterized by vomiting, lethargy, acute hemolytic anemia, renal and liver damage, neurotoxicity, increased blood pressure and respiratory rates. In some cases, it Leads to coma and death.

In comparison to the standards, The Turkish acceptable limit and EU limit for Lead was $0.40 \mu \mathrm{g} / \mathrm{g}$, (EU, 2001; TFC, 2002), permissible value by Malaysian Food Regulation (1985) is $2.00 \mu \mathrm{g} / \mathrm{g}$, by Hong Kong Environmental Protection Department (HKEPD, 1987) it is 6.00 $\mu \mathrm{g} / \mathrm{g}$ ' by USEPA (2000) it is $0.491 \mu \mathrm{g} / \mathrm{g}$, by FSANZ (2002) is $0.200 \mu \mathrm{g} / \mathrm{g}$, by EUROPA (2004) it is $0.100 \mu \mathrm{g} / \mathrm{g}$. The result obtained of Lead concentration exceeds the permissible level of all the above regulations, the result detected exceed the limit permissible level; (FAO, 1983; EC, 2001), the Turkish Food Code (TFC, 2002), European Union (EU, 2001) limit of 0.03 $\mathrm{mg} / \mathrm{kg}$ United State Environmental Protection Agency (USEPA, 2000) $0.43 \mathrm{mg} / \mathrm{kg}$ Food Standards Australia New Zealand (FSANZ, 2002); $0.200 \mathrm{mg} / \mathrm{kg}$ EUROPA (2004); 0.100 $\mathrm{mg} / \mathrm{kg}$. However, the obtained result in this study far above the limit set by Hong Kong Environmental Protection Department (HKEPD, 1987); $2.00 \mu \mathrm{g} / \mathrm{g}$ and United States Food and Drug Administration (USFDA, 1993); $3.70 \mu \mathrm{g} / \mathrm{g}$. For Zinc the lowest concentration detected was in kidney and lungs, permissible limit for Canadian food standard is $100 \mu \mathrm{g} / \mathrm{g}$, by Australian standard $10 \mu \mathrm{g} / \mathrm{g}$ (Papagiannis et al., 2004) is $50 \mu \mathrm{g} / \mathrm{g}$, and by Turkish standards (TFC, 2002) is $50 \mu \mathrm{g} / \mathrm{g}$, Zinc concentration exceeds the above regulations. For Copper $(\mathrm{Cu})$, the Canadian food standard recommend $100 \mu \mathrm{g} / \mathrm{g}$, the range of international standard is $10-100 \mu \mathrm{g} / \mathrm{g}$, Turkish acceptable limit $20 \mu \mathrm{g} / \mathrm{g}$ (Papagiannis et al., 2004), the 
permissible limit set by the Malaysian food regulation (1985) $30 \mu \mathrm{g} / \mathrm{g}$, USEPA (1990) limit 12 $\mu \mathrm{g} / \mathrm{g}$.

There are various sources of emission of trace metals into the Nigerian environment. Indiscriminate dumping of metal containing wastes, including electronics and disposal of Lead base products such as Lead-acid and torchlight batteries is very common in the country. An example could be seen in the recent Lead poisoning that occurred in five villages (Dareta, Yargalmal, TungarDaji, Sunke and Abare) in Anka L.G.A of Zamfara State where 160 villagers with children topping the number that died and hundreds more hospitalized due the Lead released into the environment from the illegal mining of gold ore in the area. Improper dumping of materials in the rivers and landfills has accounted for environmental pollutants. These wastes are discarded indiscriminately around us and contribute to pollution of the environment and thus contaminating the soil and water bodies.

Open refuse burning can also enrich the environment with some of these heavy metals. Sources of these toxic metals could also be attributed to runoff from refuge dumps in urban and rural areas including waste dumpsites and agricultural lands. Agricultural and industrial effluents can contaminate the water bodies from which these animals drink from and thus increase their metal burden. Asonye et al. (2007) has reported high Lead and Cadmium levels in some streams, river and waterways in the Western, Midwestern and Southern region of Nigeria while, Okoye et al. (2010) has reported high levels of $\mathrm{Pb}$ (0.13-2.24 $\mathrm{mg} / \mathrm{L}$ ) and $\mathrm{Cd}(0.004-0.6 \mathrm{mg} / \mathrm{L})$ in rural water resources in some parts of South-east, Nigeria. Furthermore, Akan et al. (2007) has reported high level of Chromium in tannery industrial effluents from Kano metropolis while Ayodele et al. (1996) reported high Lead levels in some industrial effluent at Sharada industrial estate Kano. Other sources of these metals especially Lead, Cadmium and nickel could be from vehicular emission. Many countries have banned the use of Leaded petrol, but Nigeria has not yet made any categorical statement on the issue. Currently, the country imports most of her petrol, and there is usually no display at filling stations indicating whether petrol on sale is leaked or not.

The anti-nutrients concentrations (phytate and oxalate) determined gave low values. Antinutrients are not bio-accumulated; therefore, the residues in the different organs (heart, lungs, spleen, kidney, and liver) of bovines detected were far below the permissible limit set by $\mathrm{WHO} / \mathrm{FAO}$ standard.

\section{CONCLUSION}

The study confirmed the presence of heavy metals in the samples analyzed. The heavy metals present in different organs were found to be above the permissible limits set by WHO, FAO and ECC. This point out that heavy metals bioaccumulation could arise due to consumption of meat from bovines that most especially graze in contaminated areas. Therefore, there is serious need of monitoring the presence of heavy metals in bovine organs in order to advice the government and populace against the dangers associated with the bovine meat consumption. 


\section{REFERENCES}

Adebayo, G. B., Otunola G. A. \& Oladipo, F. O. (2009). Determination of Trace elements in selected organs of Bovines (Cows) for safety consumption among rural dwellers in Kwara State, Nigeria. Journal of Food Safety and Protection. 4(3): 49-5.

Aina, V. O., Binta, S., Amina, Z., Hauwa, M. S. H., Hauwa, U., et al. (2012). Determination of Nutritional and Anti-Nutrient Content of Vitisvinifera (Grapes) Grown in Bomo (Area C) Zaria, Nigeria. Advance Journal of Food Science and Technology, 4(6): 445-448.

Aranha, K. (1994). Environmental Chemistry New Age International Limited Publisher, New Delhi, pp. 213-219.

Association of Official Analytical Chemists, (1995). Official Methods of Analysis of AOAC International. 16th ed., vol. 1 (Cunnif, P. Ed.), AOAC Int., Arlington, Virginia, USA. pp. 599-612.

Chinma, C. E. \& Igyor M. A. (2007). Micronutrients and anti-nutritional contents of selected tropical vegetables grown in Southeast, Nigeria. Nigeria Food Journal, 25(1): 111- 116.

Day \& Underwood, E. J. (1986). Trace Elements in Human Nutrition. 4th Edn Academic Press New York. p.545.

Doganoc, K. S., Gacnack. (1995): Lead and Cadmium ed tropical vegetables, journal of Components in Food. 12(9): 342-352.

EI-Salam, A. B. D., Nasser, M., Shabir A., Basir, A., KalsumRais, A., et al. (2013). Distribution of Heavy Metals in the Liver, Kidney, Heart, Pancreas and Meat of Bovines (Cows), buffalo, Goat, Sheep and Chicken from Kohat market Pakistan, Life Science Journal;10(7): 67-80.

Falandysz, J. (1994). Some toxic and trace metals in big game hunted in Northern part of Poland in 1987-1991. Science Total Environment, 14(1): 59-79.

Frosile, A., Haugen, A., Hot, G. \& Horhiem, G. (1986): Levels of Cadmium in livers and kidneys from Norwegian cervides. Bulletin Enviromnental Contamination Toxicology, 3(7): 453-460.

Gasparik, J. P., Massanyi, J., Slamecka, M., Fabis, R. \& Jurcik (2004). Concentration of selected metals in liver, kidney and muscle of the Red Deer (Cervuselaphus). Journal of Environmental Science Health, 39(11): 2105-2111.

Harlia, E. \& Balia, R. L. (2010). The Food Safety of Livestock Products (Meatball, Corned Beef, Beef Burger and Sausage) Studied from Heavy Metal Residues Contamination. Animal Production, 12(1): 50-54.

Hetht, H. W., Schinner, W. \& Kreuzer (1984). Endogene und exogeneEinflusse auf die Gehalte andBlei und Cadmium Muskel-and organproben von Rehwild. Fleischwirtsch, 64(13): 967-970

Izah, S. C., Bassey, S. E. \& Ohimain, E. I. (2017). Assessment of some selected heavy metals in Saccharomyces cerevisiae biomass produced from cassava mill effluents. EC Microbiology, 12(7): 213-223.

Kigigha, L. T., Izah, S. C. \& Kpea, T. B. (2015). Microbiological quality of fermented Cassava Flakes (Gari) sold in yenagoa, Metropolis, Nigeria. Bulletin Advance Science Reserch, 4(1): 157-160.

Kotferova, J. \& Korenocova, B. (1999): Distribution of $\mathrm{Cd}$ and $\mathrm{Pb}$ in tissues and organs of free. Food Sciences and Nutrition, 4(1): 67-78.

Maclean, R. (2017). Nigeria mosque attack: suicide bomber kills dozens. The Guardian. Temperature, Climograph, Climate table for Mubi". Climate-Data.org. September 6, 2019.

Mello, D. J. (2003). Food safety: Contaminants and toxins. GABI publishing, walling ford, oxan, UK, Cambridge, MA, P 480. 
Rahman, M. M., Anim, J., Physiol, Y. \& Anim, N. B. (2013). Oxlate attributes, catalytic mechanisms, and applications". United States Department of Agriculture-Agricultural Research Service, 5(3): 225-286.

Solidum, J. M., Maylea U. S., Joelle, D., Vera, D., Ar-Raquib, D. C., et al. (2013). Quantitative Analysis of Lead, Cadmium and Chromium found in Selected Fish marketed in Metro Manila, Philippines, International Journal of Environmental Science and Development; 4(2): 23-56.

Ubwa, S. T., Ejiga, S., Okoye P. C. \& Amua, Q. M. (2017). Assessment of heavy metals in the blood and some selected entrails of Bovines (Cows)s, goat and pigs slaughtered at wurukum abattoir, Makurdi-Nigeria. Advance Analytical Chemistry, 7(4): 7-12.

United State Environmental Protection Agency USEPA, (1999). Guidance for assessing chemical contaminant, Data for use in fish advisories. Fish sampling and Analysis, 1(2): 127-141.

Vallee, B. L. \& Auld, D. S. (1990). Zinc coordination, function and structure of Zinc enzymes and other proteins. Biochemistry, 29(24): 5647-5659.

WHO/FOA, (1984). List of maximum levels recommended for contaminant by the join FOA/WHO Condex Alimentrainus Commission. 2ndedn. FOA/WHO. Rome, Italy. pp.1-8.

Xia, S., Song, Z., Jevakumar, P., Shaheen, S. M., Rinklebe, J. (2019). A critical review on bioremediation technologies for $\mathrm{Cr}(\mathrm{VI})$ - contaminated soils and wastewater. Critical Reviews in Environmental Science Technology, 49(12): 1027-1078. 